\title{
Comparison of selected anthropometric parameters and motor tests in male gravity cyclists and high school students
}

\author{
Damjan Siriški, Jan Novotný
}

Faculty of Sport Studies, Masaryk university, Brno

\begin{abstract}
The objective of our study was to compare selected parameters of body composition and motor tests results obtained with measuring of two diverse groups - elite gravity cyclists and a control group of high school students. The study was conducted in 31 male gravity cyclists (16 technical gravity disciplines, 15 downhill gravity disciplines) and 14 male school students. The average age of cyclists was 20,1 years of age $(s=2,3)$, average age of control group was $18,7(s=0,6)$. Average weight of gravity cyclists was $74,5 \mathrm{~kg}(\mathrm{~s}=9,2 \mathrm{~kg})$, average height of gravity cyclists was $179,05 \mathrm{~cm}(\mathrm{~s}=6,1 \mathrm{~cm})$. Average weight of control group was $68,2 \mathrm{~kg}(\mathrm{~s}=12,1 \mathrm{~kg})$, average height of control group was $177,1 \mathrm{~cm}(\mathrm{~s}=10,62 \mathrm{~cm})$.

Matiegka protocol was used to estimate body composition and somatotype, a battery of specific motor skills was used to determine motor skills of the two test groups.

Downhill gravity cyclists proved significantly higher mesomorphy than the control group - downhill disciplines 5,3 $(s=0,43)$, control group $4.7(s=1,05)$, and significantly higher values of test results than control group in broad jump (downhill disciplines $228,2 \mathrm{~cm} \mathrm{~s}=20,1 \mathrm{~cm}$; control group 192,4cm, $s=15,1 \mathrm{~cm}$ ), back-broad jump test (downhill disciplines $118,6 \mathrm{~cm}, s=12,8 \mathrm{~cm}$; control group $98,3 \mathrm{~cm}$, $s=13,5 \mathrm{~cm}$ ) and high jump (downhill disciplines $61,1 \mathrm{~cm}, \mathrm{~s}=11,9 \mathrm{~cm}$; control group $51,5 \mathrm{~cm}, \mathrm{~s}=12,5 \mathrm{~cm}$ ). Technical disciplines cyclists proved significantly higher values of test results than control group in broad jump (technical disciplines 214,5cm s=18,2 cm; control group 192,4cm, $\mathrm{s}=15,1 \mathrm{~cm}$ ), rotation jump (technical disciplines $510^{\circ}, s=25,4^{\circ}$; control group $430,2^{\circ}, s=39,4$ ) and high jump test (technical disciplines $112,6 \mathrm{~cm}, \mathrm{~s}=10,9 \mathrm{~cm}$; control group $98,3 \mathrm{~cm}, \mathrm{~s}=13,5 \mathrm{~cm}$ ).

Differences in somatotype, body constitution and motoric tests relate with characteristics of training and use of specific training methods. In this study high level performance athletes were tested, therefore it could be helpful for riders and coaches to increase the efficiency of the training process.
\end{abstract}

Keywords: motor skills, somatotype, training process.

\section{INTRODUCTION}

There are many factors that influence sport performance in gravity cycling disciplines. As the these disciplines are the kind of sport, where athletes perform dangerous tricks in air or overcome technical obstacles in extremely high speed, riders cope with significant risk of injury during their performance. Potential danger of injury in every moment of training or competition influences riders' mental state and is a big factor in riders' training. Elite athletes not only train to improve their technical skills and physical capacities to increase their sport performance, but also build extra muscle mass to prevent injuries associated with failure during their performance, which often results in crashing.

In our research we divide gravity cycling disciplines into two groups. Downhill disciplines, which include fourcross and downhill mtb, are typical for overcoming obstacles on 30 s to $6 \mathrm{~min}$ courses in high speed. Abilities to accelerate and handle the bike in difficult technical situations are crucial. Second group - technical disciplines include freestyle mtb and biketrial. Riders of this 
group feature abilities to overcome extremely technical tracks and use obstacles for their sport performance. Single run lasts up to $2 \mathrm{~min}$.

The physique of an athlete is considered to be an important determinant of success in many sports, and in top level sport there would appear to be a tendency for individuals to gravitate towards the event to which they are anthropometrically best suited (Foley et al. 1989).

Factors of sport performance are clearly influenced by metabolic (Allemeier et al. 1994; Dawson et al. 1998) and neural factors (Casabona et al., 1990; Nummela et al., 1994), however, anthropometric factors also play an important role (Mann et al., 1984).

Modern trends in functional anthropology are focused in study of correlation between morphologic and functional variability of human body. (Riegerová et al., 2006).

The objective of our study was to determine body composition of gravity cyclist.

\section{METHODS}

31 male elite cyclists and 14 male high school students were studied in the investigation. The average age of cyclists was 20,1 years of age $(s=2,3)$, average age of control group was 18,7 $(s=0,6)$. Average weight of gravity cyclists was $74,5 \mathrm{~kg}(\mathrm{~s}=9,2 \mathrm{~kg})$, average height of gravity cyclists was $179,05 \mathrm{~cm}(\mathrm{~s}=6,1 \mathrm{~cm})$. Average weight of control group was $68,2 \mathrm{~kg}(\mathrm{~s}=12,1 \mathrm{~kg})$, average height of control group was $177,1 \mathrm{~cm}(\mathrm{~s}=10,62 \mathrm{~cm})$.

In our research we divided gravity disciplines riders into two groups. Downhill gravity disciplines (fourcross and downhill mtb) and technical gravity disciplines (freestyle mtb and biketrial).

Each of the resulting groups contained a mixture of abilities. The control group of high school students didn't include elite sport athletes, their general sport activity consists of 2 PE lessons a week and a sport activity on a public level.

All anthropometric measurements were made by a trained and experienced observer using a standardized procedure. We used Heath-Carter method (Heath et al. 1967) to define somatotype and Matiegka method (Matiegka 1921) to define physique of cyclists.

Body weight was measured to the nearest $0.1 \mathrm{~kg}$ in fasting subjects, wearing minimal clothing, using an electronic scale (Seca 700 scale, Seca gmbh, Hamburg). Body height was measured to the nearest $0.1 \mathrm{~cm}$ using a stadiometer. Skinfold-thickness sites included triceps, biceps, subscapular, chest, abdominal, suprailiac, forearm, medial calf and thigh. These measurements were taken on the right side of the body with the Somet skinfold caliper. A sliding bone width caliper was used to assess the bi-epicondular breadths of the humerus and femur and the width of the ankle (across the lateral malleolus of the fibula and the medial malleolus of the tibia) and wrist.

The biceps, calf, femur and forearm muscle girths were measured using a steel tape according to the procedure described by Heath and Carter (Heath et al. 1967). Height was measured to the nearest centimetre following a deep inspiration and weight was measured to the nearest half kilogram. From the data obtained, ANTROPO1 software was used to calculate somatotype and physique rating for each athlete according to the methods described by Heath (Heath et al. 1967) and Matiegka (Matiegka 1921).

Participants attended 4 motor skills tests focused on explosive leg strength (broad jump - the jumper stands at a line marked on the ground with the feet slightly apart; the athlete takes off and lands using both feet; the measurement used is the longest of three tries, high jump - the jumper stands next to a wall with measurement marking; the athlete takes off and reaches to a mark on the wall; the measurement used is the highest reached out of three tries) and coordination (twist jump - the jumper stands with a line marked on the ground in between his legs; the athlete takes off with rotation and lands with both feet, back broad jump - the jumper stands at a line marked 
on the ground and aims backwards to the line with the feet slightly apart; the athlete takes off and lands using both feet; the measurement used is the longest of three tries).

The data of the two groups were compared statistically using Mann-Whitney nonparametric test in STATISTICA software.

\section{RESULTS}

A comparison between the two cyclists' groups and the control group revealed differences in somatotype and physique. The differences are summarized in Table 1 with the somatotypes presented diagrammatically in Figure 1.

The average somatotype for each of the groups was as follows - downhill disciplines endomorphy $2.4(\mathrm{~s}=0,45)$, mesomorphy 5,3 $(\mathrm{s}=0,43)$, ectomorphy $2.9(\mathrm{~s}=0,63)$; technical disciplines endomorphy $2.6(\mathrm{~s}=0,49)$, mesomorphy $4.7(\mathrm{~s}=0,69)$, ectomorphy $3(\mathrm{~s}=0,59)$; control group endomorphy $2,4(\mathrm{~s}=0,4)$, mesomorphy $4.5(\mathrm{~s}=1,05)$, ectomorphy $2,8(\mathrm{~s}=0,5)$.

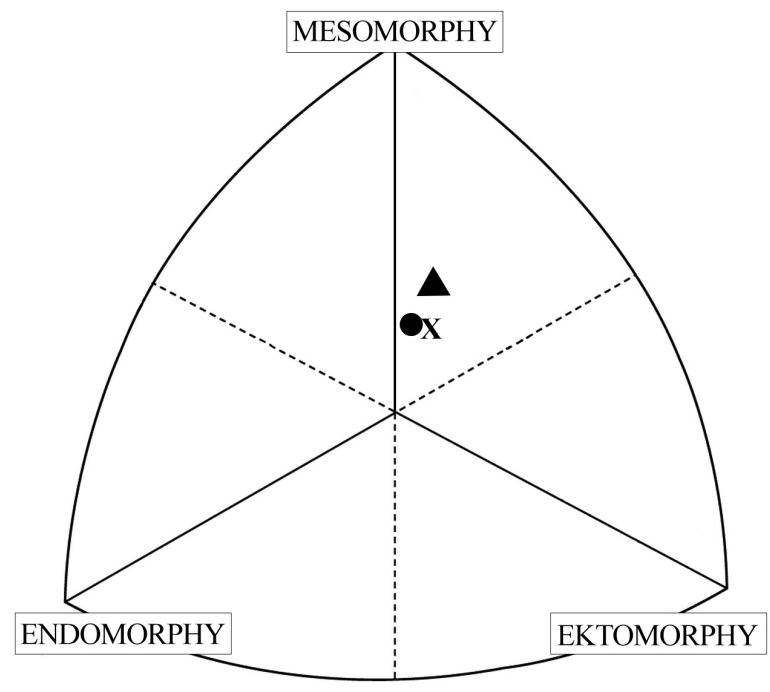

Fig. 1: Display of differences in somatotype between gravity disciplines and control group

$\Delta$ downhill gravity disciplines; $\bullet$ technical gravity disciplines; $X$ control group

Analysis of the somatotype showed the downhill disciplines group to be more mesomorphic than the control group $(p=0,05)$. No significant difference was found in the ectomorphy and endomorphy rating. 
Tab. 1: Somatotype and physique differences in downhill cycling group and control group demonstrated by Mann-Whitney nonparametric test $(p<0,05)$

\begin{tabular}{|c|c|c|c|c|c|}
\hline Variable & $\begin{array}{c}\text { Median } \\
\text { Control }\end{array}$ & $\begin{array}{c}\text { Median } \\
\text { Downhill }\end{array}$ & $\mathbf{U}$ & $\mathbf{Z}$ & p-value \\
\hline ENDO & 2,44 & 2,53 & 90,00 & $-0,91214$ & 0,341101 \\
\hline MESO & 4,58 & 5,35 & 33,00 & $\mathbf{- 3 , 1 2 0 5 2}$ & $\mathbf{0 , 0 0 1 8 0 6}$ \\
\hline ECTO & 2,86 & 2,96 & 78,50 & 1,13473 & 0,255648 \\
\hline Bone\% & 16,20 & 16,20 & 86,00 & 0,80741 & 0,419433 \\
\hline Muscle\% & 46,10 & 49,10 & 68,50 & $-1,57117$ & 0,116144 \\
\hline Fat\% & 14,05 & 13,40 & 97,50 & 0,30551 & 0,759982 \\
\hline
\end{tabular}

A comparison between the gravity disciplines group and the control group revealed significant differences in results of 3 motor skills tests.

The average result of downhill group's tests were: broad jump test $228,2 \mathrm{~cm}(\mathrm{~s}=20,1 \mathrm{~cm})$, backbroad jump test $118,6 \mathrm{~cm}(\mathrm{~s}=12,8 \mathrm{~cm})$ and high jump test $61,1 \mathrm{~cm}(\mathrm{~s}=11,9 \mathrm{~cm})$.

The average results of control group's tests were: broad jump test $192,4 \mathrm{~cm}(\mathrm{~s}=15,1 \mathrm{~cm})$, backbroad jump test $98,3 \mathrm{~cm}(\mathrm{~s}=13,5 \mathrm{~cm})$ and high jump test $51,5 \mathrm{~cm}(\mathrm{~s}=12,5 \mathrm{~cm})$.

Tab. 2: Motor skills results differences in group of downhill disciplines and the control group demonstrated by Mann-Whitney nonparametric test

\begin{tabular}{|c|c|c|c|c|c|}
\hline Variable & $\begin{array}{c}\text { Median } \\
\text { Control }\end{array}$ & $\begin{array}{c}\text { Median } \\
\text { Downhill }\end{array}$ & $\mathbf{U}$ & $\mathbf{Z}$ & p-value \\
\hline Broad jump $(\mathrm{cm})$ & 190,25 & 245,00 & 2,50 & $\mathbf{- 4 , 4 5 1 6 4}$ & $\mathbf{0 , 0 0 0 0 9}$ \\
\hline Twist jump $\left(^{\circ}\right)$ & 400,00 & 430,00 & 77,00 & $-1,20020$ & 0,229546 \\
\hline Back-broad j. $(\mathrm{cm})$ & 92,75 & 107,00 & 19,00 & $\mathbf{- 3 , 7 3 1 5 3}$ & $\mathbf{0 , 0 0 0 1 8 8}$ \\
\hline High jump $(\mathrm{cm})$ & 50,00 & 55,00 & 31,00 & $\mathbf{- 3 , 2 0 7 8 0}$ & $\mathbf{0 , 0 0 1 3 2 5}$ \\
\hline
\end{tabular}

A comparison between the technical disciplines group and the control group revealed significant differences in results of 3 motor skills tests.

The average result of technical group's tests were: broad jump test 214,5 cm ( $\mathrm{s}=18,2 \mathrm{~cm})$, twist jump test $510^{\circ}\left(\mathrm{s}=25,4^{\circ}\right)$ and back-broad jump test $112,6 \mathrm{~cm}(\mathrm{~s}=10,9 \mathrm{~cm})$.

The average result of control group's twist jump test was $430^{\circ}\left(\mathrm{s}=39,4^{\circ}\right)$.

Tab. 3: Motor skills results differences in group of technical disciplines and the control group demonstrated by Mann-Whitney nonparametric test $(p<0,05)$

\begin{tabular}{|c|c|c|c|c|c|}
\hline Variable & $\begin{array}{c}\text { Median } \\
\text { Control }\end{array}$ & $\begin{array}{c}\text { Median } \\
\text { Technical }\end{array}$ & $\mathbf{U}$ & $\mathbf{Z}$ & p-value \\
\hline Broad jump $(\mathrm{cm})$ & 190,25 & 213,25 & 22,00 & $\mathbf{- 3 , 7 2 0 5 6}$ & $\mathbf{0 , 0 0 0 1 9 9}$ \\
\hline Twist jump $\left(^{\circ}\right)$ & 400,00 & 565,00 & 19,50 & $\mathbf{- 3 , 8 2 4 4 9}$ & $\mathbf{0 , 0 0 0 1 3 1}$ \\
\hline Back-broad j. $(\mathrm{cm})$ & 92,75 & 118,50 & 17,00 & $\mathbf{- 3 , 9 2 8 4 2}$ & $\mathbf{0 , 0 0 0 0 8 6}$ \\
\hline High jump $(\mathrm{cm})$ & 50,00 & 57,00 & 75,50 & $-1,49654$ & 0,134514 \\
\hline
\end{tabular}




\section{DISCUSSION}

The control group didn't significantly dominate in any of the research's category, which might be expected, since the other groups contained elite athletes, therefor their body constitutions and motor skills are specifically developed.

The results supported suggestions that there was a high correlation between mesomorphy and body strength (White et al. 1978). Since strength is a major contributor of generating the power and obtaining a high rate of pedal revolutions (De Garay, et al. 1974), the high mesomorphy of downhill disciplines athletes might be expected. Power and obtaining a high rate of pedal revolutions is an important factor in fourcross and downhill sport performance. The lower mesomorphy ratings in technical disciplines may relate to the relative tallness of the group's athletes, which in some cases can be an advantage, especially in the task of control of executing some of the tricks, which is a part of freestyle mtb athletes sport performance.

Downhill disciplines group's significantly higher rating of broad jump and high jump results may relate to importance of explosive leg strength and ability of quicker acceleration as a major determinant of success in the downhill disciplines. This suggestion may also be connected with higher rating of mesomorphy in downhill disciplines group.

Technical disciplines group's significantly higher rating of rotation jump and back-broad jump results correlate with the long-term training process, as the sport performance in these disciplines include rotating, spinning and specific spatial orientation skillset.

Significantly higher ratings of broad jump test indicate importance of obtaining a high rate of pedal revolutions respectively demand on explosive leg power.

\section{CONCLUSIONS}

Significant difference was detected between the two groups of gravity cyclists and the control group. The downhill disciplines riders were more mesomorphic and had a higher rating of muscle mass component. The results in broad jump test, high jump test and back-broad jump test revealed that downhill disciplines riders had higher rating in the tests. Therefore it may be suggested that higher mesomorphy rating and higher muscle mass is a major contributor of generating the explosive power in legs which is a determinant of successful sport performance in downhill disciplines. The motor test results of technical disciplines riders revealed that technical disciplines riders had higher rating in the tests, which may relate with important role of coordination and spatial orientation skills in technical disciplines' sport performances as well as a test in which explosive power of legs plays a role.

It may be suggested that each form of gravity cycling disciplines may require a different optimum physique and level of motor skills rather than a general cyclist's physique for all types of competition.

\section{References}

Allemaier C. A., Fry A. C., Johnson P., Hikida R. S., Hagerman F. C., STARON R. S. (1994) Effects of sprint cycle training on human skeletal muscle. Journal of Applied Physiology 77, 2385-2290.

Casabona A., Polizzi M. C., Perciavelle V. (1990) Differences in H-reflex between athletes trained for explosive contractions and non-trained subjects. European Journal of Applied Physiology and Occupational Physiology 61, 26-32.

Dawson B., Fitzsimons M., Green S., Goodman C., Carey M., Cole K. (1998) Changes in performance, muscle metabolites, enzymes and fibre types after short sprint training. European Journal of Applied Physiology and Occupational Physiology 78, 163-169. 
De Garay A. L., Levine L., Carter J. E. L. (1974). Genetic and anthropological studies of Olympic athletes. New York: Academic Press

Heath, B. H., Carter, J. E. L. A modified somatotype method Am J Anthrop 1967, 27, 57-74

Riegrová, J., Přidalová, M., Ulbrichová, M. (2006) Aplikace fyzické antropologie v tělesné výchově a sportu: (příručka funkční antropologie). 3. vyd. Olomouc: Hanex, 262 s. ISBN 80-85783-52-5

Mann R. V., Kotmel J., Herman J., Schultz C. (1984) Proceedings of the International Symposium of Biomechanics in Sports. Sports biomechanics. Kinematic trends in elite sprinters. California. Academic Publishers.

Matiegka, J. American journal of physical anthropology

Volume 4, Issue 3, September 1921, Pages: 223-230

Nummela A., Rusko H., Mero A. (1994) EMG activities and ground reaction forces during fatigued and nonfatigued sprinting. Scandinavian Journal of Sport Sciences 26, 605-609

White, J. A., Quinn, G. Al-Dawalibi, M., Mulhall, J. A technical report submitted to the British Cycling Federation with special reference to the evaluation of the road squad's winter training programme (Nov 1978-Feb 1979) 